\title{
History and Poetry in Alonso de Castillo Solórzano's Historia de Marco Antonio y Cleopatra (1639)*
}

\section{Cleopatra in the Golden Age}

While Spain's literary Golden Age did not produce an outstanding and enduring portrayal of Cleopatra, the Egyptian queen maintains a discreet presence in the written production of the period. She features on stage and in verse, in miscellanies, treatises and histories, but only occasionally is she placed front and centre. Before Francisco de Rojas Zorrilla's Los áspides de Cleopatra, performed in the early 1640 s, ${ }^{1}$ her only definite appearance on stage is in Diego López de Castro's Marco Antonio y Cleopatra (1582), ${ }^{2}$ although we can suppose that she played a significant role in Lope de Vega's now lost Los triunfos de Octaviano, written before $1604 .{ }^{3}$ Cleopatra is afforded a poetic treatment in 1550, in two of the pieces of Alonso de Fuentes's Libro de los cuarenta cantos (II.i, 'Vencido va Marco Antonio', and III.iv, 'Mal se querella Cleopatra'), both of which are followed by lengthier, moralising prose glosses (Fuentes 1587, 90v-104v, 288v-302r). Yet we must then wait almost a century for Francisco de Borja's Canto de Antonio y Cleopatra, published in stand-alone form in 1640

\footnotetext{
* This study was undertaken under the auspices of the research project $\mathrm{I}+\mathrm{D}+\mathrm{i}$ La novela corta del siglo XVII (y II) (FFI2013-41264-P), funded by the Spanish government's Ministerio de Economía, Industria y Competitividad and headed by Prof. Rafael Bonilla Cerezo of the Universidad de Córdoba.

1 On Rojas Zorrilla's play, published in the Segunda parte of his drama in 1645, see González Cañal 2008. This critic notes the possible influence of Castillo Solórzano's Historia de Marco Antonio y Cleopatra on Los áspides de Cleopatra, though any similarities are ultimately superficial and unconvincing, and he discusses briefly the two subsequent dramatic representations of Cleopatra in seventeenth-century Spain: Marco Antonio y Cleopatra, undated and of unknown authorship, and Los tres señores del mundo by Luis Belmonte Bermúdez, published in 1653.

2 For a short description and full transcription of the play, which survives in manuscript, see Rennert 1908.

${ }^{3}$ The title of this play features in Lope's own list of his dramatic output to date in El peregrino en su patria, of 1604 (Vega 1973, 60).
} 
and shortly thereafter included in his collected Obras en verso (Borja 1648, 110-145). The memorable and marvellous episode of Cleopatra's pearls, derived from Pliny's Natural History (9.119-121), appeals to writers compiling, however credulously, factual works, from Pedro Mexía, in his Silva de varia lección (1540) (Mexía 2003, 620621) and Diálogos o Coloquios (1547) (Mexía 2004, 300-301), to Andrea Pescioni's translation (1586) of Pierre Boaistuau's Histoires prodigieues (1560) (Boaistuau 1586, 90v), and Juan de Pineda's Diálogos familiares de la agricultura cristiana (1589) (Pineda 1963-64, vol. 1, 220-221). ${ }^{4}$ If Pescioni, through Boaistuau, places the event in the aweinspiring context of the sumptuous entertainments to which the Egyptian queen treated Antony upon their initial acquaintance, the speakers in Pineda's colloquy place the event in a broader continuum of Cleopatra's outrageous behaviours ('Otros mayores daños hizo en el mundo como deshonesta'), and refer the reader back to Pineda's own Monarquía eclesiástica (1588). There, Cleopatra garners two whole chapters (36 and 37, at the end of the ninth book [Pineda 1588, vol. 1, 364v-369r]), the most ambitious individual treatment of the century and one in which Cleopatra's immorality, lasciviousness and greed emerge even more strongly than they had in Mexía's Historia imperial y cesárea (1545) (Mexía 1655, 1-34), where Cleopatra plays an important role in the accounts dedicated to Julius Caesar and Augustus. ${ }^{5}$

Alonso de Castillo Solórzano's Historia de Marco Antonio y Cleopatra (1639) coincides with Pineda and Mexía's portrayals in a number of respects, historical and ethical, and Castillo Solórzano confesses a debt to both works. The seventeenthcentury text differs substantially from these predecessors, however, in making Cleopatra its main focus, the centre around which the rulers and generals of her day, including the titular Antony, orbit. The work is published in Zaragoza in $1639,{ }^{6}$ at the

\footnotetext{
${ }^{4}$ On these, see Sainz de la Maza 2009.

${ }^{5}$ On the portrayal of Cleopatra in these two works, see Jiménez Belmonte 2011b, 287-305.

6 The fact that one of the book's approbations and its Suma del privilegio are signed in the Aragonese capital in October 1635 indicates its status as a finished work four years or so before its eventual publication, and may indicate that Castillo Solórzano was acting on the expiry of a ten-year privilege taken out on the 1625 version of the work. The same approbator, Diego
} 
end of a decade which saw the publication of the author's most ambitious - and disparate - books, but we have evidence that a primitive version of the work was ready for publication as early as 1625.7 The approbations to Castillo Solórzano's Tiempo de regocijo, a text published in Madrid in 1627, are signed by Juan de Jáuregui and Francisco Boil two years earlier, and they mention respectively a 'Vida de Cleopatra' and a 'Historia de Cleopatra' (Castillo Solórzano 1907, 184, 185). ${ }^{8}$ No publication of this sort is extant, and it is reasonable to suppose that the manuscript in question went on to become the 1639 work..$^{9}$ Another fair supposition concerns the formal complexion of this initial redaction; we can posit with some certainty that the 1625 incarnation of the history did not boast - to anything like the same degree, if at all - what proves to be most singular characteristic of the later, published work: its mixture of prose and poetry, with twenty-seven poems, by Castillo Solórzano himself and an assortment of other major and minor figures, inserted irregularly at more or less opportune points from the second to the fourteenth, and last, chapter. The identity of a number of the contributors (especially the non-Castilian ones) is enough to scotch the idea that the 1625 history contained the same poetic element, and we can assume also that the presence of significant figures such as Lope, Juan Pérez de Montalbán

Amigo, signs off simultaneously Castillo Solórzano's Patrón de Alcira and Las aventuras del bachiller Trapaza, which are published respectively in 1636 and 1637, and the three works are enumerated together in the privilege of Patrón de Alcira. We can understand the staggered publication of the three works as a sensible commercial strategy, with the printer Pedro Vergés and the author wishing not to saturate the market, although the gap between 1637 and 1639 is unexplainable, as is the decision taken, presumably with the author's consent, by another notable Zaragozan printer, Diego Dormer, to publish also in 1639 the Epitome de la vida y hechos del ínclito rey don Pedro de Aragón.

7 On Castillo Solórzano's life and works, see Bonilla Cerezo 2012.

8 In the closing lines of Tiempo de regocijo, the author promises, should the present work meet with public satisfaction, to 'dar a la estampa a La reina Cleopatra' (Castillo Solórzano 1907, 435). ${ }^{9}$ On an earlier instance of Castillo Solórzano reworking his texts, his rapid conversion of the Escarmientos de amor moralizados, published in Seville in 1628, into the Lisardo enamorado, published in Valencia the following year, see Giorgi 2014. 
and José de Valdivielso might have been something which Jáuregui especially would have flagged up as noteworthy - as indeed Diego Amigo did in his approbation to the definitive version - were their poetry a feature of the early text. ${ }^{10}$

There is no doubt that Castillo Solórzano's Historia de Marco Antonio y Cleopatra is the most substantial prose treatment of the figure of Cleopatra in the Spanish Golden Age, and the author's decision to embed almost thirty poems within the history means that it is the Golden Age's major contribution to her poetic representation as well; not all of the poems in the work take as their subject Cleopatra herself, although few are fully unrelated to her, and it is possible to anthologise those which do concern Cleopatra to produce a fragmentary poetic biography of the Egyptian queen. In both respects Historia de Marco Antonio y Cleopatra merits a scholarly attention which has not generally been forthcoming. In this article, therefore, I shall examine the two facets of Castillo Solórzano's Historia de Marco Antonio y Cleopatra, its prose history and its poetic fragments, singularly and in conjunction. The relationship between the two forms and its outcomes are aspects of the work in which the writer himself displays little evident interest. In his short foreword to the history, Castillo Solórzano does draw attention to the poetry of the volume, but he does so only as part of a self-deprecating captatio benevolentiae; he humbly seeks his readers' good will and forestalls criticism of his qualities as a historian by highlighting the rectifying role served by 'los grandes poetas que le honran [este volumen] con sus elegantes versos, padrinos de que me he valido' (Castillo Solórzano 1639, 'Prólogo'). Nor are there concerted remarks in the body of the history on the ways in which the prose and poetry might complement each other or create dualities, although this is not to say that it is impossible to extract implicit assumptions or to form sensible conclusions regardless of Castillo Solórzano's intentions or any lack thereof. I shall first examine the prose make-up of the history, concentrating on its purposes and on the way in which Castillo Solórzano assembles his sources to achieve these; I shall

\footnotetext{
10 Jáuregui had himself published a sonnet on Antony's defeat at Actium and Cleopatra's role in it; 'Sobre las ondas acosado Antonio' is the first composition after the long Aminta in his Rimas (Jáuregui 1618,93), one which therefore occupies a structurally important position.
} 
demonstrate too that the work is not only a mosaic of prose and poetry, but that Castillo Solórzano's tessellates a number of prior historians to create specific effects. In subsequently analysing the poetry of the book, I shall acknowledge its unevenness of quality and of integration within specific parts of Castillo Solórzano's history, but I shall also assess the function exercised by a number of pieces within the overall historical fabric of Historia de Marco Antonio y Cleopatra. The poetry of the volume possesses an extrinsic significance, in so far it affords us insights into Castillo Solórzano's literary networks and contacts with professional and amateur writers which had been glimpsed more dimly in his previous works, and suggests a drive at literary self-promotion in the mid-1630s; the most recent addition to these networks, Francisco Diego de Sayas, is also the most prominent poet in the volume, save Castillo Solórzano himself, and this most likely represents a strategic choice, as the author sought to position himself in his new Aragonese context. Sayas, himself a historian and an erstwhile poet, will be the spur for some concluding considerations on prose and poetry at the service of historiography.

\section{The Prose of Castillo Solórzano's Historia de Marco Antonio y Cleopatra}

\section{2.i. Contents and Purposes}

Jáuregui, Boil and Castillo Solórzano's own allusions solely to Cleopatra in their references to the now lost 1625 version of the history should not induce us to assume that the Egyptian queen was the only focus of this earlier work, nor should we take the eponymous emphasis on Cleopatra and Antony in the 1639 text as an indication of a narrow purview; indeed, Cleopatra's extensive involvement with crucial figures around the start of the Imperial Period of Rome would render such narrowness untenable. If the work begins with a genealogy of the Ptolemaic dynasty, of which Cleopatra, the seventh of that name in the dynasty, will be the final representative, substantial portions of the second and third of the fourteen chapters which comprise the text concentrate respectively on the struggle between Julius Caesar and Pompey, culminating in the victory of the former at Dirrachium, and the conspiracy against, 
and assassination of, Caesar in Rome. ${ }^{11}$ The involvement of Egyptian figures in these events is undoubtedly important, from Pompey's treacherous murder on the orders of Ptolemy Theos Philopator to Cleopatra's affair with Caesar, resulting in the birth of their illegitimate son, and their alliance against her brother and rival, Theos, but the focus is firmly on the politics of Rome. It is only in the fourth chapter that the second titular protagonist, Mark Antony, is introduced, as the events following Caesar's death are recounted, and the fraught circumstances leading up to the creation of the Second Triumvirate outlined. We are thus introduced to Lepidus and Octavian, the latter of whom would go on to become Caesar Augustus, and who, after Julius Caesar, Antony, and Cleopatra, is the fourth major figure of the history, one who, after the suicides of Antony and Cleopatra, will merit a chapter and a half of his own at the end of the book, as Castillo Solórzano takes us forward to the Pax Augusta, a providential condition for the coming of Christ and indicative of a broader providential approach to Roman history in Castillo Solórzano's text. The relationship between Antony and Cleopatra, personal and political, therefore occupies around two-thirds of the work; the particulars of the history reserve no surprises for the reader familiar with the various classical accounts of the partnership, from Cleopatra's sumptuous arrival along the Cydnus when summoned by the triumvir, and the subsequent love affair which befuddled Antony's good judgement, to his calamitous defeat by Octavian's forces in the naval battle at Actium, and the eventual, contrasting suicides of the pair - his maladroit, hers cunning - in Alexandria. ${ }^{12}$

The purpose of the history is, throughout but especially in the cases of Antony and Cleopatra, an exemplary one. In his dedication to the work, Castillo Solórzano (1639, 'Dedicatoria') describes the historical figures who populate it as 'varones ilustres', an epithet which encompasses both 'hechos [...] heroicos y honestos' and 'los opuestos a ellos'; one should emulate the former, upstanding, behaviours, and from

\footnotetext{
11 On the Ptolemaic dynasty and its relations with Rome, see Sullivan 1990, 81-95, 229-279.

${ }^{12}$ On Cleopatra and her role in the last years of pre-imperial Rome, see Kleiner 2005 and Jones 2006. On Cleopatra and Antony's relationship in particular, see Goldsworthy 2010, especially 218-396, and Volkmann 1958, 90-207.
} 
the latter 'huir de su dañosa imitación, con el escarmiento de sus violentos y desdischados fines', a formulation which indicates that Castillo Solórzano, not unexpectedly, has in mind especially the titular couple and their spectacular demise. This express wish for exemplarity, of course, is not at all unusual in the literature of the Spanish Golden Age, and particularly not in history-writing; the historiographer Luis Cabrera de Córdoba, working in the generation before Castillo Solórzano's, asserts in his influential vernacular ars historica of 1611 that history is 'la narración de verdades por hombre sabio, para enseñar a bien vivir', in which the writer should be found 'condenando los vicios, alabando las virtudes' and contributing to 'la guardia de la prudencia y del decoro' (Cabrera de Córdoba 1948, 24, 27). What imbues Castillo Solórzano's account with some peculiarity, however, are the compositional methods by which that exemplarity is generated, the splicing of sources and literary forms to a clearly defined moral purpose, as we shall see over the course of this study. Though Castillo Solórzano frequently points up the moral messages which should be drawn from the events as he recounts them, the plainest expression of such didacticism - in its negative permutation - comes as Castillo Solórzano evaluates the import of Antony and Cleopatra's story:

Sirva de ejemplo la pérdida de Antonio para que los hombres no se cieguen en sus pasiones y libidinosos apetitos, pues este era un valeroso y fuerte capitán, experimentado en cualquiera trance [...], y olvidado de sus obligaciones, hechizado con la hermosura de una libre Reina de Egipto, fue vencido de su contrario, aborrecido del Senado, dado por enemigo de la Patria, y últimamente muerto desesperadamente [...]. Sirva asimismo de ejemplo, para que las mujeres se guarden, la libertad y desenvoltura de Cleopatra, el demasiado cuidado en aderezarse y componerse, porque las madres (a cuyo cargo está la crianza de sus hijos) les eviten esto cuando es con demasiado exceso; pues, de usarlo para parecer bien a los hombres, suceden mil desgracias y afrentas por 
casas y familias ilustres, con que vienen a menoscabo su fama. (Castillo Solórzano 1639, 137-138)

Both characters, therefore, have much to teach their respective gender, but if, nominally, the lesson imparted by the pair is a balanced one, in fact a much larger portion of blame is heaped on Cleopatra, an approach firmly in keeping with the use of her in the period as a negative paragon of the female; for instance, in a lengthy conduct manual at the end of the sixteenth century, the Franciscan Juan de la Cerda employs Cleopatra to exemplify the perils of beauty, 'la hipocresía de la mujer', sumptuary extravagance, and promiscuity (Cerda 1599, 30v, 459v, 473r, 568v). ${ }^{13}$

Nevertheless, Cleopatra is not painted in an uncompromisingly censorious fashion, for Castillo Solórzano affords her a decidedly back-handed compliment in saying that 'tuvo mucho de gran señora y mucho de mujer ordinaria, y, para decirlo con más propiedad, de ramera' (Castillo Solórzano 1639, 138), and, in a less ambivalent sense, she is shown ultimately to be distraught by Antony's death, a proof, at least in part, of some genuine affection for him (113-114). Furthermore, the other personages who are scrutinised in the work are also shown to have inherent flaws, quite independent of Cleopatra's intervention; the first presentation of Antony is much less than flattering, for instance, ensuring that we will not view him simply as a weak victim of Cleopatra's eventual machinations: 'Estaba a la sazón Marco Antonio muy poderoso, siendo cónsul, y a esto se juntaba el ser muy arrogante' (36). While the depiction of Julius Caesar in the early part of the work is a generally positive one, in which he laments the unbefitting murder of his foe, Pompey, and shows himself to be magnanimous with his adversary's vanquished men, his weakness for women ('demasiado dado a amores de mujeres' [18]) is presented negatively and, indeed, with the illegitimate birth of Caesarion, his son with Cleopatra, he bequeaths a political problem in flesh and blood to his successors (23). We are informed also that, though

\footnotetext{
${ }^{13}$ In the latter two considerations, Cerda in fact follows, in content and in wording, material from Pineda's chapters dedicated to the Egyptian queen in Monarquía eclesiástica.
} 
Octavian is largely correct in moving war against his fellow triumvir, he is not motivated entirely by just grievances: 'Más esclarecido nombre ganara Octaviano César, si las guerras que movió contra Antonio, las hiciera sin ambición de verse con su muerte absoluto señor del mundo' (139). Yet, if male figures are privileged numerically in Castillo Solórzano's text, the thematic predominance of Cleopatra is confirmed by her being the only character to garner an obvious counterpoint, in the form of Octavia, Octavian's sister and Antony's fourth wife, an 'honesta matrona' (82) who serves as a positive model of compassion and forbearance, 'siendo en ella costumbre hacer bien a todos' (69).

For Castillo Solórzano, this cast of ethically imperfect noble protagonists has much to teach any ordinary reader of his history, and he doubtless agrees with the principle of Cerda's assertion - on Cleopatra's promiscuity - positing 'las reinas y grandes señoras' as an 'espejo en que se miran todas las otras mujeres' (Cerda 1599, $568 \mathrm{v}$ ), and so, by extension, the use of illustrious figures as specula for the classes below. Yet, we glean also in Castillo Solórzano's dedication - to Juan de Moncayo, an Aragonese nobleman of the Habit of Santiago and a Gentilhombre de la Boca to Philip IV, as the frontispiece of Castillo Solórzano's book proclaims - a more directly political application of a history which he terms an 'epílogo que incluye acciones de tan poderosos monarcas, inclítos reyes y fuertes capitanes' (Castillo Solórzano 1639, 'Dedicatoria'), ensuring that the work fulfils another of the characteristics posited for history-writing by Cabrera de Córdoba, the pragmatic instruction of high-placed individuals: 'Uno de los medios más importantes para alcanzar la prudencia tan necesaria al príncipe en el arte de reinar es el conocimiento de las historias' (Cabrera de Córdoba 1948, 11). The use of Antony and Cleopatra as exemplars of poor governance and decisions in the arts of ruling and diplomacy is found in Francesco Patrizi's neo-Latin De Regno et Regis Institutione (published posthumously in 1519, but probably completed in the early 1480s), translated into Spanish by Enrique Garcés as De reino y de la institución del que ha de reinar in 1591; as we find in Castillo Solórzano's history and other Spanish texts which treat the lovers, a capital emphasis is placed on the vitiation of Antony's capacity to govern by the feminisation of his character when 
subjected to the rampant, excessive femininity which Cleopatra embodies. ${ }^{14}$ Garcés's 'Marco Antonio se subjectó mucho al amor y efeminó las fuerzas y esfuerzo del ánimo en tanto grado' and 'ablandado, y efeminado, o quizá enhechizado con los amores de Cleopatra, perdió el brío de ánimo y cuerpo que solía tener' (Patrizi 1591, 170v, 193r) are echoed in statements by Castillo Solórzano such as 'estas y otras cosas [...] afeminaron el ánimo de Marco Antonio de tal manera que dejó de todo punto la guerra que intentaba hacer' (Castillo Solórzano 1639, 68). Through his noble, regal and imperial protagonists, Castillo Solórzano dwells frequently on matters of military and diplomatic strategy and tactics, both in the internal Roman context and further afield, on the correct moments for clemency and severity, on the importance of reputation and on abdication of responsibility, forgivable in a private individual, perhaps, but potentially fatal for those who exercise power:

¿Quién creyera de un tan valiente capitán como Marco Antonio (cuyo esfuerzo hemos visto en las hazañas atrás referidas) que, olvidado de sus obligaciones, se sujetara a la voluntad de una mujer, [...] con menoscabo de su reputación y menosprecio del enemigo. (56)

Furthermore, at two critical moments in the text he refers to Cleopatra's calculations vis-à-vis her own rule as her 'Reason of State', a loaded term in the politics of the period: 'solo miraba su particular razón de estado' (89), as she influences Antony's choice of a naval battle, and, as Castillo Solórzano sums up her failings, we hear that she betrayed her lover twice, 'mirando más a su razón de estado que a la opinion de reina' (138). ${ }^{15}$

This is not to say that we should attempt to separate out the desired moral and political impacts of the history, for there is clear overlap, and, in particular, the former

\footnotetext{
${ }^{14}$ On the dangers of feminisation posed by Cleopatra, see Jiménez Belmonte 2011b, 294-300. ${ }^{15}$ On ‘Reason of State' in seventeenth-century Spain, see Fernández-Santamaría 1980, and Gil Pujol 2003.
} 
strongly informs the latter. Castillo Solórzano writes and publishes his book in a period in which the reading and study of histories, modern and ancient, was viewed as indispensable to the contemporary effectiveness of a Spanish monarchy which faced a number of threats, some long-standing and others newly emergent. ${ }^{16}$ The particular store placed in historical writings by Philip IV and his advisors, in both the king's formative and governing years, is well documented, and is especially pertinent to Castillo Solórzano's Historia de Marco Antonio y Cleopatra, for its lengthy gestation is located in the first two decades of Philip's reign. This is not to claim for Castillo Solórzano's book any definitely shaped political programme, for it is a modest, popular history composed by a young writer who was relatively unknown - in 1625, to be sure - , and who even by the mid-to-late 1630s had not achieved a reputation for gravity in his literary work. Nevertheless, the very fact of Historia de Marco Antonio y Cleopatra, and its content, are no doubt to some extent conditioned by the spirit of the age, and the history might be imagined as possessing certain, varying connotations, whether these were intended or not, at the three critical junctures in its redaction: in 1625, when the primitive version of the text was passed fit for publication in Castile; in 1635, when the definitive version of the work received its approbations for Aragon; and, in 1639, when it was eventually published. We can assume that the text of the prose history would have been broadly similar in both versions, such is Castillo Solórzano's reliance on a small number of sources, from which he derives the vast majority of the detail of his history, as we shall broach shortly. The early years of Philip IV's reign - he had acceded to the throne at the age of sixteen in 1621 - ran generally smoothly and contained a number of successes, but certain negative details from Castillo Solórzano's book might be expected to evoke less favourable echoes even in 1625; for instance, Antony and Cleopatra's very unbecoming habit of gallivanting around Alexandria in disguise in order to engage in scandalous behaviour (Castillo Solórzano 1639, 57-58) is not greatly removed from Philip's similarly incognito (but not especially covert) 'nocturnal sallies into the backstreets of

16 On history-writing and its functions in the first part of Philip IV's reign, see Kagan 2009, 207-235. 
Madrid' with the Count-Duke of Olivares, the valido of the new king, in the first years of Philip's reign (Stradling 1988, 52). By the 1630s, much had changed; the end of the previous decade had seen a succession of territorial losses for Spain, and, though some momentum had returned to Spain by the middle of the following decade, France's declaration of war in May 1635 marked for Spain the beginning of 'epoch of total war [...] as the 1630s twisted into an ever-tighter spiral of sacrifice and crisis' (Stradling 1988, 129). The near-constant military engagements of Castillo Solórzano's history, which compresses the bellicosity of Pompey, Julius Caesar, Antony and Octavian, and other related protagonists, into just 150 vertiginous octavo pages might have seemed prescient in October 1635, and would undoubtedly have struck a most resonant chord by 1639, when Castillo Solórzano's book was finally published, not least in light of the less than impressive performances of Spain's navy. ${ }^{17}$

\section{2.ii. Sources and Composite Effects}

In his provision of moral and political paradigms from the ancient world, particularly from Roman history, Castillo Solórzano is far from alone in the historiography of the Spanish Golden Age; illustrative in this regard, albeit far more ambitious, is Mexía's Historia imperial, noted earlier in this study. In his prologue, Mexía, chronicler to Charles $\mathrm{V}$, posits history as the most valuable resource for those who are called upon, by office or by birth, to rule, while recognising a dual utility for history, for, if 'los reyes y príncipes hallan en la historia otros a quien imiten y con quien compitan en virtudes y excelencias, y otros malos de cuyas costumbres huyan, y de cuyos fines y fama escarmienten', equally 'este fruto y provecho es común a todo género de hombres' (Mexía 1655, 'Al letor'). ${ }^{18}$ Though this conception of historywriting is commonplace in the period, our citation of it is not gratuitous, for this work

\footnotetext{
17 'The problem was that the tide was now turning against Spain. In 1637 the Dutch recaptured Breda; in 1638 the key Rhine fortress of Breisach was taken by France's allies, while in August the French wiped out a Spanish naval force in the little harbour of Guetaria (near San Sebastian); in 1639 the Dutch under Tromp defeated the Spanish fleet at the battle of the Downs (October)' (Kamen 1991, 208).

18 On Mexía's conception of history and its written record, see Pocock 2003, 239-257.
} 
by Mexía is explicitly acknowledged by Castillo Solórzano when, at the very end of Historia de Marco Antonio y Cleopatra, our author purports to provide a list of his sources:

Los autores que escriben todo lo que se ha dicho en este breve volumen son Tito Livio, Cornelio Tácito en su primer libro, Plutarco en la Vida de Julio César, Josefo en el libro décimo de las Antigüedades, Lucano en el primero y segundo libro, Pineda, y Pedro Mexía en sus Césares. ${ }^{19}$ (Castillo Solórzano $1639,150)$

At first viewing, this enumeration seems to represent a sincere wish to confess his debts, as well, naturally, as conferring solidity upon the preceding material by attributing its content to unimpeachable authorities. The text itself is not especially rich in avowed citations or acknowledgements, although, in addition to some of the names in his terminal list, Castillo Solórzano cites, with varying degrees of specificity, Suetonius, Orosius, Pliny the Elder, Ovid, Athenaeus, Cassius Dio, and Galen. However, the apparent plain-speaking of Castillo Solórzano's final list conceals, in a number of ways, his true methods of construction in this highly composite history. Of the two Spanish authors cited, Castillo Solórzano prefers by far Mexía's Historia imperial to Pineda's encyclopaedic Monarquía eclesiástica; indeed, we can be certain of the use of this latter text in only two parts of Historia de Marco Antonio y Cleopatra: in both cases, taken from the same page of Pineda's work (1588, vol. 1, 302v), Castillo Solórzano has recourse to it as an intermediary source, first to provide a detail from

\footnotetext{
${ }^{19}$ For an overview of classical historiography comprising the life and actions of Cleopatra, see Volkmann 1958, 220-228, and Williamson 1974, 2, 26-31; Williamson notes that Renaissance portrayals of Cleopatra differ from their counterparts in the Middle Ages, as Plutarch's psychologically nuanced material (especially in his Life of Antony) supplants, as the main source of information on the queen, the sterner, moralistic portraits provided by the Latin historians Paterculus and Florus.
} 
Josephus's Jewish Antiquities (15.4) on Cleopatra's treacherous lust for absolute power in Egypt and its environs (Castillo Solórzano 1639, 72), and then to cite Galen on a manual written by Cleopatra on make-up and alluring clothing (121-122). ${ }^{20}$ Mexía's history, on the other hand, furnishes a majority of the material on Julius Caesar and on the creation of the second triumvirate and its participants' initial manoeuvrings, and on the actions of Octavian subsequent to the deaths of Antony and Cleopatra, meaning that Mexía's content bookends the narrative of the titular lovers, a couple whose trajectory the sixteenth-century historian largely neglects, except when it intersects with the progress of Octavian towards his destiny as Caesar Augustus, such is Mexía's work's focus on the Emperors of Rome. ${ }^{21}$

Castillo Solórzano's heavy dependence on the earlier writer for a substantial portion of his history is by no means unusual in a period in which the notion of intellectual property is significantly weaker than our own, with Castillo Solórzano's principal modification of his source text consisting of compression and omission of details in order to render the new text less annalistic and more readable (albeit still clearly recognisable as counterfeit when subjected to parallel examination), but it is notable that Castillo Solórzano seeks to throw his reader off the scent by claiming in his terminal list of sources that he has consulted 'Plutarco en la Vida de Julio César'. ${ }^{22}$ There is no likely direct use of Plutarch's life of Julius Caesar in Castillo Solórzano's history, and the supposed direct citations from Plutarch in this opening part of the work either hail intermediately from Mexía's text (for which Plutarch is indeed a

20 The marginal note in Pineda's text directs the reader to Galen's De Compositione Medicamentorum Secundum Locos, 1.2; a match can be made to that part of the physician's treatise, but Pineda is guilty of caricaturing the reference to Cleopatra's putative Cosmetics, as Galen refers to her remedies for alopecia and damaged hair.

${ }^{21}$ Castillo Solórzano 1639, 6-45 follows Mexía 1655, 8-22, in which Julius Caesar is the avowed topic up to p. 18, whereupon Octavian's history begins. Castillo Solórzano 1639, 135-149 follows 1655, 30-34, albeit less closely than in the earlier material.

22 On the assumptions - implicit and explicit - which condition the borrowing and reworking of materials in non-fiction works in the period, and on the unseen use of intermediate texts to promote a false vision of scholarship, see Bradbury 2016. 
major source) or are introduced artificially by Castillo Solórzano so as to promote the impression of true consultation of the Greek historian on this topic. It is only when Mexía summarises Antony's time in Egypt with the succinct assertion that 'Marco Antonio se dio a vicios y deleites después en Egipto con la Reina Cleopatra' (Mexía $1655,22)$ that Castillo Solórzano's history necessarily diverges from Mexía's text, and joins up instead with its second principal source, which will provide a great majority of the material on Antony and Cleopatra: Plutarch's life of Antony, which Castillo Solórzano picks up in its twenty-fifth section and adapts, with little acknowledgement, through to its end. ${ }^{23}$ In light of this actual use of Plutarch, therefore, how should we interpret Castillo Solórzano's false claim of having consulted Plutarch's life of Julius Caesar? We might attribute to it two purposes: firstly, that he wishes to conceal his total dependence on a single modern source for this part of Historia de Marco Antonio y Cleopatra; this concealment is further aided by two subsidiary falsehoods, in so far as Castillo Solórzano's references to Livy and Lucan, found sparingly in the treatment of Julius Caesar and flagged up in his terminal list of major sources, proceed not from Castillo Solórzano's scrutiny of the primary texts but via Mexía as well. And, secondly, his supposed candour in

${ }^{23}$ Castillo Solórzano's ‘ Pasó Marco Antonio a Asia, con ánimo de hacer guerra a los partos, gente belicosísima, y, llegando a Cilicia, envió desde allí un criado, llamado Duelio, a decir a Cleopatra que viniese luego a dar cuenta personalmente, porque había ayudado a Casio su enemigo con gente y dineros' (Castillo Solórzano 1639, 45) corresponds to Plutarch's 'As he was getting ready for the Parthian war, he sent to Cleopatra, ordering her to meet him in Cilicia in order to make answer to the charges made against her of raising and giving to Cassius much money for the war' (Plutarch 1920,191). Similarly, the concluding lines on Marc Antony and Cleopatra in Castillo Solórzano's history ('Los demás hijos [de Marco Antonio] se entregaron a Octavia, que, aunque era su madrastra, los crió, y tuvo siempre en grande estima, y después casó a Cleopatra hija de Antonio con el Rey Juba') (Castillo Solórzano 1639, 134-135) correspond to part of the eighty-seventh, and last, section of Plutarch's Life of Antony: 'The rest were taken up by Octavia and reared with her own children. Cleopatra, the daughter of Cleopatra, Octavia gave in marriage to Juba, the most accomplished of kings' (Plutarch 1920, 331). 
confessing a seemingly major debt to a single work by Plutarch distracts from an even more substantial - yet unconfessed - real debt to that same author's life of Antony.

From this we should not understand that Castillo Solórzano is wholly dependent on Plutarch's account of Antony and Cleopatra, for within this main section of the narrative we find do details taken from other authors; we have seen the cases of Josephus and Galen, covertly borrowed from Pineda, and we also find material from Pliny's Natural History (the celebrated episode of the pearl), an account of Cleopatra's visit to Herod, likely based on Josephus (Jewish Antiquities, 15.4), and a description of the first banquet presented by Cleopatra to Antony which bears greatest resemblance to the details provided by Athenaeus in his Learned Banqueters (4.147148). ${ }^{24}$ However, the source second in importance to Plutarch's life of Antony in this section of the book is Cassius Dio's Roman History, a conjunction, albeit one which is weighted heavily towards Plutarch, which is alluded to only once by Castillo Solórzano, and, even then, only in indistinct terms: 'Muchos errores hizo Antonio, siendo valeroso capitán y de mucha experiencia, los cuales pudiera remediar y ser vencedor, como se verá en Plutarco y en Dión, que escriben su vida' (Castillo Solórzano 1639, 87). ${ }^{25}$ Yet, it is in this combination that the principal historiographical interest of the work lies, a knitting together that Castillo Solórzano, given his scant humanist formation, achieves not by recourse to the original Greek texts, or even their Latin translations, but rather through the Italian translations published in the previous century, by Lodovico Domenichi (1555) and Francesco Baldelli (1565) respectively. To the longer, lucid and always credible narration from Plutarch which vertebrates the main section of Historia de Marco Antonio y Cleopatra, Castillo Solórzano imports details and episodes from Dio, a historian severely criticised as unreliable by Cabrera de

\footnotetext{
${ }^{24}$ Whether any of these three cases proceeds directly from Pliny, Josephus and Athenaeus, or whether they derive from intermediate texts, such as anthologies, is uncertain; on the use of such compendia in the early-modern period, see López Poza 1990.

25 The parts of Dio's Roman History relevant to Castillo Solórzano's text are found between 48.24 and 51.15 of the classical work.
} 
Cordoba in 1611, which either augment or replace analogous sections of Plutarch's account. ${ }^{26}$

The most involved example of such inter-weaving - albeit one which goes unseen, such is Castillo Solórzano's reticence to overburden his narration with attributions at every turn - is found in the prose which recounts the desperate manoeuvring of Antony and Cleopatra after the battle at Actium (Castillo Solórzano $1639,99-104)$. The description of the experiments with various poisons carried out by Cleopatra, before she settles on the asp, is derived from Plutarch $(1555,366),{ }^{27}$ while the three possible options (flight to Spain, where some resistance to Octavian lingers, which might be fomented to their advantage; escape via the Red Sea; or commissioning the assassination of Octavian) which open the next chapter, the tenth, are taken instead from Dio $(1565,553) .{ }^{28}$ Cleopatra's unrealistic proposal that Octavian allow Antony to go into exile in Athens and that her children be allowed to rule in Egypt hails from Plutarch $(1555,366)$, but Cleopatra's perfidy which follows this in Castillo Solórzano:

\footnotetext{
${ }^{26}$ As well as noting that Dio has attracted criticism for including superstitious material in his accounts, Cabrera de Córdoba deems him more sweepingly one of those writers who 'mienten entre los griegos [...] en las cosas de Assiria, Egipto y Fenicia' and a historian who 'en las antigüedades romanas falt[a] a la verdad' (Cabrera de Córdoba 1948, 83, 45, 100). On Dio's merits and shortcomings as a historian, see Millar 1964, especially 28-72. While Plutarch is not considered beyond reproach in Cabrera de Córdoba's treatise, such as in his supposed tendency, along with Dio, to over-elaboration (Cabrera de Córdoba 1948, 81), he is labelled as a historian who has written truthfully about Greece (45) and Rome (60), and who can render potentially salacious material chastely (84).

27 The cumulative material used in Castillo Solórzano's Historia spans Plutarch 1555, 340-373.

28 The block of Dio's text relevant to Castillo Solórzano's Historia is Dio 1565, 513-561; Castillo Solórzano draws material in particular from the latter part of this range, and also follows if not verbatim, in tenor - the highly moralising summary of Antony and Cleopatra's fatal deficiencies in Dio 1565, 561.
} 
Y Cleopatra, de secreto (sin que Antonio fuese sabedor de esto) envió a César un cetro y una corona de oro, y la Silla Real de los Reyes de Egipto, que era pieza riquísima y todas tres de inestimable valor, por sobornarle con estos dones, para que disimuladamente le entregase a ella el Reino; y que si la enemistad era con Antonio, de ella, por lo menos, tuviese misericordia. (Castillo Solórzano 1639, 102-103)

is absent in Plutarch but present in Dio $(1565,553)$. Castillo Solórzano follows Dio $(1565,553)$ once more in describing Octavian's reaction, but the details of Thyrsus's embassy on behalf of Octavian stem from Plutarch $(1555,367)$, despite a similar account being present in Dio $(1565,555)$. When, shortly afterwards, Octavian triumphs at Pelusium, Castillo Solórzano follows Dio's opinion (1565, 556), according to which Cleopatra's betrayal of the city and her lover is certain, rather than simply a possibility, as it is in Plutarch, although he does add a closing detail from Plutarch $(1555,367)$ : Cleopatra's decision to inculpate Seleucus and to hand over his wife and children to Antony so that he might avenge himself upon them.

Castillo Solórzano's strategy here should be clear: he opts to present a version of events in which Cleopatra is consistently depicted in the worst possible light. Indeed, the other additions which he makes to Plutarch's account, from Pineda, Josephus and others, noted previously, are designed to amplify the negative aspects of the Egyptian queen's character - treacherousness, manipulativeness, excess - , but it is through Cassius Dio that Castillo Solórzano can best achieve this aim. Pelling notes that, while the first third of Plutarch's Life of Antony, and its terminal comparison, with Demetrius, is clearly moralistic, this feature is toned down notably once Cleopatra is introduced: '[T] he story is immediately seized by a new narrative and descriptive vigour [...] There are no more intrusive moralizing remarks; no more explicit denunciations of the actions he describes. [...] Praise and blame are alike irrelevant to the narrative' 
(Pelling 1995, 149). ${ }^{29}$ Pelling notes elsewhere that Plutarch treats Antony's infatuation and its effects with 'psychological empathy', and, in comparison with the historians on this subject who preceded and came after him, he furnishes 'a portrait of greater humanity [...] [and] deserves credit for such imaginative compassion' (Plutarch 1988, 18). ${ }^{30}$ While Castillo Solórzano can, therefore, take advantage of such narrative depth to generate a readable and arresting history, he twists it to a distinct moral purpose, whether through addition or substitution. So, as Castillo Solórzano's Cleopatra returns to Alexandria after Antony's defeat at Actium (Castillo Solórzano 1639, 9596), fearing a revolt from her people should the loss become known immediately she decks out her ships in victorious pomp and uses the time which this affords her to execute potential enemies and to raise funds by plundering her subjects. This detail is not found in Plutarch, for 'such ruthlessness has no place in Plutarch's view of Cleopatra's world' (Plutarch 1988, 290), but it is in Dio's account $(1565,552)$, and hence is implanted by Castillo Solórzano. Castillo Solórzano differs to from Plutarch, too, in his version of the crucial scene of Cleopatra's interview with Octavian (Castillo Solórzano 1639, 121-124); he not only makes Cleopatra a more active participant - by having her, rather than the triumvir, initiate the meeting - , and changes the location from the mausoleum to Cleopatra's palace, both details in which he follows instead Dio $(1565,558)$, but rather he replaces wholesale Plutarch's account of an emotionally and physically destitute woman ('lying on a mean pallet-bed, clad only in her tunic [...] her hair and face were in terrible disarray, her voice trembled, and her eyes were sunken' [Plutarch 1920, 321, 323]), with a substantially different picture of a master manipulator, one who will use beauty, charm and emotional blackmail - through her evocation of Octavian's adoptive father, and her previous lover, Julius Caesar - to

\footnotetext{
${ }^{29}$ Wilamowitz-Moellendorf notes that the 'gripping scenes' once Cleopatra is introduced in the Life of Antony are 'completely different in tone from what one can glimpse in the other Roman Lives' (Wilamowitz-Moellendorf 1995, 69).

30 Pelling's detailed commentary on the text (Plutarch 1988, 117-327) identifies the commonalities and differences between Plutarch's Life and the treatment of Antony by other classical authors, particularly Dio.
} 
try to obtain Octavian's pity, and in this Castillo Solórzano once more follows Dio $(1565,558)$ :

Sabido esto por Cleopatra, mandó aderezar su casa con las más ricas y costosas colgaduras que tenía [...] El vestido con que Cleopatra recibió esta visita fue de luto, que este hábito le estaba más bien, aunque con cualquiera parecía siempre hermosa [...] Para aguardar esta visita se sentó en una silla, y en torno de ella puso cerca de sí muchos retratos del primero César. Y asimismo tenia consigo michas cartas que de éste había recibido, y copias y borradores de otras que ella le había escrito estando ausente. (Castillo Solórzano 1639, 121-122)

That her scheme for clemency is, in both accounts, unsuccessful is of no relevance in this connexion. On occasion, this interspersing of the two major sources can generate inconsistency. For instance, though Castillo Solórzano follows Plutarch's - slightly more detailed - version of Thyrsus's embassy to Cleopatra on behalf of Octavian, shortly afterwards he incorporates a reference which is taken from Dio, to the effect that Cleopatra was deceived by the promise of Octavian's love relayed by Thyrsus (Castillo Solórzano 1639, 105); this promise was indeed mentioned in Dio's account of the embassy, but is not found explicitly in Plutarch's, meaning that a slightly narrative kink is created.

\section{The Poetry of Castillo Solórzano's Historia de Marco Antonio y Cleopatra}

The matter of integrating materials from diverse hands becomes even more pertinent - and sometimes more problematical - when we turn to the other type of content found in the volume: its twenty-seven poetic compositions. In his short prologue, as we noted in the introduction to this piece, Castillo Solórzano deprecatingly proposes the poetry of the volume, which he attributes to 'grandes poetas' who have kindly acted as 'padrinos' to the text, as a supposed means of compensating his deficiencies as a historian, specifically in the 'disposición de la Historia' (Castillo Solórzano 1639, 
'Prólogo'). Twelve authors other than Castillo Solórzano contribute poems to the volume: Gaspar Mercader, Juan Pérez de Montalbán, Francisco Tamayo y Porres, Jacinto Navarro, Vicente Gascón de Siurana, José de Valdivielso, Monserrat de Cruyllas, Luis de Villanova and Sancho de Molina y Soto provide a piece each, although this last figure also donates the sole preliminary poem to the history; we have two poems each by Francisco Novella and Lope de Vega; and there are three by Francisco Diego de Sayas, meaning that he is the best represented author, with the exception of Castillo Solórzano himself, who includes eleven of his own poetic pieces. Of the twenty-seven poems, seventeen appear in the part of the history focused on Antony and/or Cleopatra, seven treat the figures of Pompey and Julius Caesar in the earliest stage of the text, and three deal with the feats of Octavian in the last section of the book. Almost all of the compositions are sonnets, though we do encounter two sets of octavas: one of these is the first composition by Novella, and the other is by Gascón de Siurana.

We might quibble with Castillo Solórzano's description of his collaborators as 'grandes poetas', for, while many of the poems are of good quality, only Lope, Pérez de Montalbán, Valdivielso and Mercader can be considered established literary figures; the other contributors are talented, and now largely forgotten, amateurs whose poetry sprang principally from literary academies or certámenes, although the tentative hypothesis advanced by King $(1963,127-128)$, whereby the Historia de Marco Antonio y Cleopatra would bear indirect witness to an academic session dedicated to the figure of Cleopatra during Castillo Solórzano's sojourn in Valencia is complicated by the fact that of the seven Valencian writers represented, only four contribute poems pertaining directly to Cleopatra, and all of these compositions concern the later stages of that history, from the Battle of Actium to the death of the Egyptian queen. ${ }^{31}$ The

\footnotetext{
${ }^{31}$ Mercader writes on Pompey and the Battle of Dyrrachium, Molina y Soto on Pompey's flight from Pharsalus, and Novella on Caesar's assassination, while the four Valencian compositions on Antony and Cleopatra are: Navarro on the triumvir's disastrous strategising on the eve of Actium, Gascón de Siurana on the battle itself, Cruyllas on Octavian's visit to Cleopatra, and Villanova on Cleopatra's tomb.
} 
preponderance of Valencian poets does, nevertheless, reflect the importance of that city in Castillo Solórzano's movements around the Peninsula in the third and fourth decades of the century, first with Luis Fajardo de Requeséns and then with his son Pedro Fajardo y Zúñiga, for both of whom Castillo Solórzano served as a maestresala, ${ }^{32}$ and it is reasonable to suppose that he encountered at least some of the contributors to his Historia in the academies of the city. ${ }^{33}$ Of the five poets unconnected to Valencia, four are most associated with Madrid, while Francisco Diego de Sayas is not only the best represented author in the history but also the only Aragonese, attributable perhaps to the fact that Castillo Solórzano had only just moved to Zaragoza when the work was submitted for publication. Jiménez Belmonte (2011a, 321) is therefore largely correct to term this mixed volume 'una suerte de academia virtual' which encompasses three significant urban contexts (Valencia, Madrid, Zaragoza), and, as in the academies of the real world, amateur poets, often from a noble or scholarly background, rub shoulders with the big beasts of the literary scene. ${ }^{34}$

Castillo Solórzano associated with Lope's literary circle - in which we find Valdivielso and Pérez de Montalbán - in Madrid in the 1620s, and we can document also his association with other poets from Historia de Marco Antonio y Cleopatra in the paratexts of his previous works: Navarro, Gascón de Siurana, Cruyllas, and Tamayo $\mathrm{y}$ Porres had all contributed laudatory décimas to the preliminaries of Lisardo enamorado, published in Valencia in 1629, and another décima by Tamayo y Porres is found in the dedicatory materials of Castillo Solórzano's Huerta de Valencia, also

\footnotetext{
32 Luis Fajardo was appointed Viceroy of Valencia in 1628, and, upon his death in 1631, the post was given to his son Pedro, who held it until 1635. Though Castillo Solórzano may have spent a period of two or three years in Barcelona in the early 1630s, Valencia is the most important city in his life at this time; see Castillo Solórzano 2012, 13-14.

${ }^{33}$ Mas i Usó, in examining Valencian academies, provides details on four of the authors who contribute to Castillo Solórzano's history: Gascón de Siurana, Mercader, Navarro, Novella (Mas i Usó 1999, 450-451, 471-472, 479, 480).

${ }^{34}$ On Francisco de Mendoza's Academia de Madrid, of which Castillo Solórzano was secretary in the mid-1620s, see Kennedy 1968.
} 
published in the eponymous city in the same year. The first novela in Castillo Solórzano's Noches de placer (Barcelona, 1631), 'Las dos dichas sin pensar', is dedicated to Mercader, the most notable of the Valencian academicians, and the third, 'La ingratitud y el castigo', is addressed to Cruyllas, whose poem in Historia de Marco Antonio y Cleopatra, 'En un estrado que sostiene ufano', on the interview of Cleopatra with Octavian (Castillo Solórzano 1639, 125), does not sit especially comfortably with Castillo Solórzano's prose, as it seems more likely based on Plutarch's, rather than Cassius Dio's, account. Molina y Soto is the best represented author in this respect, however, for he had contributed to the preliminaries of Castillo Solórzano's Huerta de Valencia, Patrón de Alcira and Escarmientos de amor moralizados (1628). We also find a romance by Molina y Soto, 'Cuando los hados se indignan', placed and praised in the narrative of Castillo Solórzano's Fiestas del jardín (Castillo Solórzano 1634, 147-151), and similarly a piece by Villanova in this same metre, 'Oh, qué linda sales, niña', is embedded in the fiction of the Huerta de Valencia, where it is sung in the last divertimiento of the work to introduce a comedia (Castillo Solórzano 1944, 224-225).

However, if Castillo Solórzano is one of the foremost practitioners of mixed literature in the Spanish Baroque, the swathes of poetry which he includes in works whose primary mode is prose are generally his own, and it is this fact which renders Historia de Marco Antonio y Cleopatra, where a majority of the poems are not penned by him, unique within his oeuvre. ${ }^{35}$ In most cases, the function of the poetry is one of two sorts: to enhance an episode presented in the prose of the volume, by summarising, recapitulating or amplifying it, or to highlight its moral import, but in no case does a poem replace a section in prose, meaning that the poetry is, regardless of other qualities, interpolated, rather than fundamental to the text. For instance, Villanova's sonnet, 'Esta que así alentada se resiste' (Castillo Solórzano 1639, 133-134), which demonstrates both culto and conceptista features, memorialises Cleopatra and Antony's joint tomb, introduced in the preceding paragraph, while Molina y Soto's earlier sonnet, 'Para que el corazón más denodado' (11-12), reiterates details of Pompey's escape from Pharsalus and proposes that the reader 'pruebe la utilidad del

35 On Castillo Solórzano as an author of multiformal works, see Arredondo 2006. 
escarmiento' inherent in the general's downfall. These are two of the most successful pieces in the volume, both intrinsically and in their incorporation within Castillo Solórzano's broader text, whereas the first of the two sonnets by Lope, 'Cleopatra a Antonio en oloroso vino', the only poem from the history to have appeared previously in print, though it is of no little literary merit, is forced quite maladroitly into its new position. ${ }^{36}$ The sonnet is an obvious choice to illustrate one of the most famous and evocative episodes in the Cleopatra legend, her dissolving a pearl in a glass of wine to impress Antony, a scene which Castillo Solórzano in fact treats perfunctorily in his prose, given its absence from the Plutarchan account, and Castillo Solórzano acknowledges correctly that Lope's piece features already 'en sus Rimas, que es el tercero'; however, he makes no effort to adapt the composition to eliminate the final apostrophe to Lope's female recipient, one 'Lucinda', who is hyperbolised through reference to the pearl: 'Quedó la perla sola en testimonio/ de que no tuvo igual hasta aquel día, / bella Lucinda, que naciste al mundo' (Castillo Solórzano 1639, 54).

The quality of two other compositions was recognised just less than a decade after the publication of Historia de Marco Antonio y Cleopatra, by Gracián in his Agudeza $y$ arte de ingenio (1648). In the fiftieth of the discursos in this second iteration of the treatise, on 'la perfección de los estilos en común', Gracián affirms that 'dos cosas hacen perfecto un estilo: lo material de las palabras y lo formal de los pensamientos' (Gracián 2004, vol. 2, 608), and, of the seven Spanish pieces which he uses to exemplify his considerations on the theme, he derives two from Castillo Solórzano's history: sonnets by Valdivielso and Sayas, placed respectively in the significant first and last positions of Gracián's chapter $(609,615-616)$. Both of these poems, “"Recibe, oh mi Cleopatra, la postrera' (Castillo Solórzano 1639, 115), a fine example of sermocinatio, and 'Sutilizando filos a la muerte' (100), illustrate scenes towards the end of Antony and Cleopatra's lives, concerning his suicide and her experiments with fatal poisons; of the first Gracián asserts that 'encierra mucha alma' and demonstrates 'facilidad del

\footnotetext{
36 This poem is the second of the collected poems added to Lope's La hermosura de Angélica in 1602 , and would appear as the third piece when these poems were published independently, as the Rimas of 1604 (Vega 1993-94, vol. 1, 190-191).
} 
decir', and of the second we hear that it embodies 'la intensa profundidad del verbo' and 'mucha sutileza' (Gracián 2004, vol. 2, 608, 615). However, although both authors are churchmen, they are not equal in fame, for, if Valdivielso was an active member of the Madrid intelligentsia and the author of the religious epic Vida, excelencias $y$ muerte de San José (1604), a work to which both Castillo Solórzano and Gracián allude, and which had enjoyed over 20 editions by the mid-1630s, Francisco Diego de Sayas (1598-1678) is a figure largely lost to modern criticism, one of those gifted amateurs who, after Castillo Solórzano's compositions are taken into account, contribute the bulk of the remaining poetry to the history. ${ }^{37}$ Although he may not vindicate Gracián's billing as 'entre los de primera clase' (Gracián 2004, vol. 2, 615), he is of especial interest in the context of Historia de Marco Antonio y Cleopatra, in that, aside from Castillo Solórzano, he is the most prolific collaborator (with three sonnets, all on the titular protagonists) and the only Aragonese poet represented therein. Fourteen years after the publication of Castillo Solórzano's mixed history, in 1653, Sayas would be appointed Cronista del Reino de Aragón, a post which he would hold until 1669, and it is largely upon this role that his intellectual legacy now rests, although he was well respected in the period as a poet as well. ${ }^{38}$ In the nineteenth Part of Lope's Comedias, the Fénix dedicates La mocedad de Roldán to Sayas, then in his mid-twenties; this address is a response, Lope says, to Sayas's own dedication to him of a now lost poem - we cannot be sure whether in manuscript or print, though the former seems slightly more likely - entitled the Castalia (Vega 1624, 235-237). ${ }^{39}$ Lope announces here, too,

37 On Valdivielso, see Jauralde Pou 2010, vol. 2, 556-576.

38 On Sayas's life and works, see Monreal Casmayor 2000 and Zaragoza Ayarza 2009). His major printed undertaking resulting from his role as Cronista is the Anales de Aragón desde el año de MDXX [...] hasta el de MDXXV (Zaragoza: Herederos de Pedro Lanaja, 1666).

${ }^{39}$ Lope praises Sayas's 'fábula' in unusually emphatic terms: 'Es aquel poema de lo más puro y elegante que sufre la imitación de la antigüedad en nuestra lengua, las figuras y locuciones tales que, hablando por sí mismas, me dan la excusa de encarecerlas y me dejan la envidia para imitarlas' (Vega 1624, 236). One can assume that the poem treated the - not especially common - myth of the transformation by Apollo of the water nymph Castalia into the fountain that bears her name on the lower slopes of Parnassus; on this figure in classical 
that further praise will follow in his Laurel de Apolo, and indeed it did when that work was published in 1630; in the second silva of the Laurel (lines 759-770), Lope underlines the affection that the Muses have for 'el acento blando / de sus hermosos versos', and he compares Sayas favourably to Horace and Virgil; he also stresses Sayas's attachment to his homeland, a note struck too in the earlier dedication, and deems him one of the 'glorias de Aragón' (Vega 2007, 227-228). ${ }^{40}$

In this part of Lope's text dedicated to Aragonese wits, Sayas is enumerated third, behind only the Leonardo de Argensolas, and it seems that Sayas moved in the same literary circles as Bartolomé and enjoyed a close friendship with him. He contributed to the posthumous first edition of the collected poems of Lupercio and Bartolomé, in 1633, the sole dedicatory poem to the volume as a whole (a sonnet, 'Los dos collados que admiró la aurora') and the only introductory piece to the part of the text set aside for the compositions of Bartolomé: a 184-line elegy, 'Murió Bartolomé; cedió a la suerte', at the head of which Sayas identifies himself as 'triste como amigo

literature, see Parke 1978. That the piece might have been of considerable extension is implied by Lope's reference to not wanting to get carried away and provide 'comentos' to Sayas's poem - the notion of a commentary applied to a short composition would make little sense -, but this Castalia is not mentioned by Latassa $(1799,551-558)$ in his otherwise detailed summary of Sayas's life and works in the third volume of his Biblioteca nueva, which covers los escritores aragoneses que florecieron desde el año de 1641 hasta 1680; that Latassa allots Sayas to this period is an acknowledgement that his most enduring works, historical texts relating to Aragon, were written then, although he does mention a number of occasional poems by Sayas published in various places in the earlier part of the century.

${ }^{40}$ If Lope's placement of the now obscure Sayas with Horace and Virgil seems overblown, it is of a piece with more possible praise of Sayas's Castalia, in Lope's mythological poem $\mathrm{La}$ Andrómeda, published in La Filomena in 1621; Lope's reference to the fountain brings an equivalence between Homer and Virgil, and an unnamed modern poet (Vega 1621,121r), and, although Cossío $(1998$, vol. 2, 358) was inclined to see a boastful reference to Lope himself here, more likely is an allusion to Sayas's poem. 
suyo' (Leonardo de Argensola 1634, ๆ3v, 149-155). ${ }^{41}$ The first attested poem by Sayas seems to be his contribution to the preliminaries of Francisco Marcuello's Historia natural y moral de las aves (1617), published when Sayas was not even twenty years of age, and we have evidence of his participation in the same year in poetic celebrations in Zaragoza commemorating the translation of relics relating to Raymond Nonnatus. ${ }^{42}$ Similarly, some time after his appearance in Castillo Solórzano's history, in 1649, we find his contribution to the literary competition in Huesca celebrating the marriage between Philip IV and Mariana of Austria; through the proceedings of these certámenes, we possess both Sayas's canción ('A las mayores bodas prometida') and the information that he placed first in his chosen category and won two silver candlesticks (Félix de Amada 1650, 33v-35r, 135r-135v. It is tempting to suppose, too, that he participated in the activities of the Academia de los Anhelantes in Zaragoza, whether as one of the regular académicos or as an occasional invitee, but of this we have no definitive proof. ${ }^{43}$ What is certain, though, is that in the 1640s Sayas felt himself to possess sufficient authority in the field of Aragonese letters to present to Antonio de

${ }^{41}$ On the early textual history of these Rimas, and Sayas's part in it, see Dadson 2010, especially $55-63$.

42 His sonnet 'La esposa enferma pide fruta y flores' is recorded in Martín 1618, 46v. In 1619 he entered poems - a set of octavas, 'Áncora de la fe, con cuyo zelo', and a sonnet, 'En láminas de oro, en jaspe duro' - into the competitions held in Zaragoza to celebrate the elevation of Fray Luis Aliaga to the post of Grand Inquisitor (Díez de Aux 1619, 89-91, 180). In the verse sentencia which summarises the fifth certamen, Sayas is referred to with the following quatrain: ‘Con versos gallardos luego, / galán don Francisco Diego / de Sayas y Ortubia vino, / cuyo ingenio peregrine / goza de Elicona el riego' (290). This is another reference to Sayas's lost Castalia, for the other mooted location for the spring was Mount Helicon, and demonstrates that the poem was circulating and had achieved at least some regional renown when Sayas was still only twenty-one years of age.

43 This academy was conceived by Juan Francisco Andrés de Uztarroz, a friend of Sayas and his predecessor as Cronista del Reino de Aragón (1646-53), and was active between 1628 and his death in 1653; in a letter of 1652, Sayas suggested to Uztarroz that some of his own work be submitted for commentary at a session of an academy, presumably that of his correspondent (Zaragoza Ayarza 2009, 10). 
Aragón a comprehensive review of the region's poetry, from Martial to the contemporary age, as an appendix and extension to a manuscript edition of the recently deceased Martín Miguel Navarro’s poetry (Blecua 1945, 291-317).

We have noted above that, save Castillo Solórzano, Sayas is the most prolific poet in the volume, and, if we break down further the poetic complexion of the central part of Castillo Solórzano's history, that which deals particularly with Antony and Cleopatra, his significance only increases. Discounting from the seventeen poems therein Lope's previously published 'Cleopatra a Antonio en oloroso vino' and removing Castillo Solórzano's own compositions, we are left with ten original poems by eight authors, of which almost a third are by Sayas. The first of these ('Blanda pasión contra el rigor de aquella' [Castillo Solórzano 1639, 56-57]) treats the neglect by Antony of his military and political responsibilities due to his infatuation with Cleopatra, ultimately the keynote of Castillo Solórzano's history, while the latter two examine the association of Cleopatra and poison: 'No temió Antonio la beldad, veneno' (80-81) summarises the scene in which Antony's fears of Cleopatra as a treacherous poisoner reach a head before the Battle of Actium, and 'Sutilizando filos a la muerte' (101) centres upon Cleopatra's experiments with various poisons as she seeks an appropriate method of suicide following the pair's military catastrophe, before settling on the asp. The importance of the last of these three is boosted retrospectively, as Castillo Solórzano inexplicably does not include a poem on Cleopatra's eventual, iconic suicide, by asp bite. Sayas also garners one of the lengthier introductions afforded to a poet in the volume; this presentation is notable for its allusion to Sayas having supposedly abandoned the cultivation of poetry for weightier pursuits, an assertion which implicitly heightens the worth of the poem being presented (and by extension the two which feature later in the text), such is its supposed rarity as an unpublished composition by one who has now stopped penning poetry:

A este asunto escribió el agudo y sutil ingenio de don Francisco Diego de Sayas este soneto, que en él está su alabanza, habiéndola merecido en 
muchos escritos suyos que publican la erudición de su dueño. Escribióle en tiempo que con la espada cortaba la pluma, y, ya en diferente hábito, dado a mayores estudios, no solicita las Musas, con no poco sentimiento de los que pierden el gozar de sus dulces versos.44 (Castillo Solórzano $1639,56)$

While we can affirm with certainty his previous contact with most of the poets represented in the volume, Sayas's participation entails a further unknown, for we have no record of a prior acquaintance, literary or otherwise, between the two men. However, whether Sayas's collaboration in the volume constituted their first direct contact or not, Castillo Solórzano's decision to foreground in this mixed history a highly respected Aragonese intellectual - one who had left a great impression on Castillo Solórzano's friend and mentor, Lope, as we have seen - comes to represent a significant element in a sustained bout of self-promotion which accompanied Castillo Solórzano's move to Zaragoza in the first half of 1635 with his master, Pedro Fajardo y Zúñiga, who had been appointed Viceroy of Aragon. Other elements in Castillo Solórzano's drive to increase his visibility in the region include his choice of dedicatees in this period: he offers Patrón de Alcira, a text which, properly understood, is a Valencian work, to Baltasar Navarro Arroytia, Bishop of the important Aragonese diocese of Tarazona; Historia de Marco Antonio y Cleopatra to Juan de Moncayo, not

\footnotetext{
${ }^{44}$ Antonio, writing later in the century, provides similar information regarding Sayas's change of direction after his ordination as a priest in the 1620s: 'poeta olim, cum nondum sacris initiatus fuisset' (Antonio 1672, vol. 2, 323-324). Latassa's bio-bibliography of Sayas records no poems by him in print between 1619 and the date of publication of Castillo Solórzano's Historia de Marco Antonio y Cleopatra; in that same year of 1639, Sayas contributes a short prose encomium and a sonnet ('Estas cenizas que apuró la llama') to the volume commiserating the death of Pérez de Montalbán (Grande de Tena 1639, 63r-63v), a composition clearly of a different nature to the three pieces on Antony and Cleopatra.
} 
only the Marquis of San Felices but also a poet of some renown on the regional stage; ${ }^{45}$ Aventuras del bachiller Trapaza to Juan Sanz de Latrás, first holder of the recently created - in 1625 - Countship of Atarés, near Huesca; and Epítome de la vida y hechos del ínclito rey don Pedro de Aragón, in manuscript copy to Juan Funes de Villalpando, first Marquis of Osera, a title created just a decade earlier (1626), and, in printed form, to Antonio Jiménez de Urrea, Count of Aranda. Indeed, his decision to pen this regional history, passed for publication in October 1636, should be understood as an attempt to consolidate regional sympathies in much the same way that his Sagrario de Valencia (1635), a compendium of hagiographies relating to the Kingdom of Valencia which is dedicated to the titular city, represented his fond and ambitious sign-off to a region where he had been based for over five years.

That the publication of both the Epitome and his Historia de Marco Antonio y Cleopatra, works passed legally fit for publication for publication four and three years earlier respectively, was postponed until 1639 (after mid-May in the latter case), would doubtless have dampened the contribution of these works to any enduring selfpromotion of the author in Aragon, given his departure along with his master for Barcelona the following year, although the dedicatees would not necessarily have been unaware of the works soon to appear dedicated to their name (and indeed, as noted above, the Epitome had a manuscript dedicatee, too), and we can assume also that Castillo Solórzano's mid-decade collaboration with Francisco Diego de Sayas

45 On this figure, see Arco 1950 and Moncayo 1976, vii-xxxvii. Moncayo had apparently published an edition of his Rimas in Lérida in 1636, described in some detail by Latassa (1799, 320-321), though no copy of this survives, and we can surmise the existence of a Madrid edition between this date and the publication of the surviving edition of 1652; what is clear is that Moncayo had become known for his poetic talent in the court circles of Madrid and in his native Aragon over the course of the 1630s. As was the case with a number of Castillo Solórzano's dedicatees in this period, Moncayo's noble standing had in the preceding years been burnished, not only by his investiture in the Order of Santiago but by his inheriting the Marquesado de San Felices, a marquisate created for Moncayo's mother, Francisca de Gurrea, as recently as 1634 and which he obtained following her death in 1636. 
opened up potential avenues of entry into the region's intelligentsia. ${ }^{46}$ Indeed, it is no surprise to find Castillo Solórzano rubbing shoulders with a number of writers from Zaragoza's thriving intellectual scene (and a number of figures of substance from Madrid as well) in the multitude of dedicatory poems to another - far weightier historical work published by Pedro Vergés in Zaragoza in 1639: the second part of the Aragonese Juan Agustín de Funes's Coronica de la ilustrísima milicia y sagrada religión de San Juan Bautista de Jerusalén. ${ }^{47}$ To this cavalcade of praise, Castillo Solórzano lends a sonnet ('De la heroica milicia del Bautista'), remarkable only for its sheer conventionality and conformity. At the end of these preliminaries, however, we find an altogether more significant composition: a prologue, by Francisco Diego de Sayas, which goes far beyond mere introduction or encomium of the work in question and becomes a de facto concise guide to the art of history-writing, replete with learned citations in Latin and in Spanish translation. This should not, of course, surprise us, given Sayas's intellectual formation and his practical endeavours as a historian and, later, as an official regional chronicler, but it should impress upon us the deliberately dual suitability of Castillo Solórzano's choice of Sayas as the only Aragonese writer represented in his hybrid Historia de Marco Antonio y Cleopatra. In this discourse, Sayas expounds the virtues of linguistic clarity and discusses the correct degrees of artifice with which to dress histories; though he does not suggest decorating history-writing with poetry, immediately before concluding his prologue with a set of laudatory tercets of his own, he does make a point of some relevance to our present investigation,

\footnotetext{
${ }^{46}$ Though Fajardo y Zúñiga's Viceroyship had changed from that of Aragon to that of Navarre in mid-1638, his residence, in Zaragoza, remained the same. His Viceroyship of Catalonia, begun in 1640, was resoundingly unsuccessful; he failed to quell the revolt of the Catalans, and was removed from the position in 1641. His time in Barcelona did, at least, allow Castillo Solórzano to publish there his Alivios de Casandra in 1640.

47 Authors contributing preliminary verses who can be identified with the Zaragozan poetic milieu include Juan de Moncayo, Diego José de Funes, Juan Francisco Andrés de Uztarroz, Martín Miguel Navarro, Martín Peyrón y Queralt, and Miguel Bautista de Lanuza. From Madrid's literary scene participants include Lope, Antonio Coello, Cristóbal Salazar de Mardones, Antonio Martínez de Meneses, Tomás Tamayo de Vargas, and Alfonso de Batres.
} 
albeit without developing it: 'según nuestro español Fabio Quintiliano: Tiene parentesco [la historia] con la poesía, y en cierta manera es verso desatado' (Funes 1639, 'A los lectores' $) .48$

\section{Conclusion: Verse as History}

Sayas's citation of Quintilian's commonplace should prompt us to some final considerations regarding the relationship between the prose and verse of Historia de Marco Antonio y Cleopatra, and the role of the latter in Castillo Solórzano's writing of this history. As we noted in the opening part of this study, the author declines to use his foreword or dedication to address the interaction of the two sorts of materials, and the remarks which introduce or succeed the poems in the course of the history shed a similarly minimal amount of light on the interconnectedness of the forms. Generally, Castillo Solórzano limits himself to praising his contributors' literary prowess in its own right, whether through his formulaic mentions of their 'ingenio' - of the twelve participating poets, only poor Monserrat de Cruyllas lacks this epithet - or some variant of 'agudeza', or through more personalised, but still cursory, considerations, such as his introduction of the 'agudo ingenio' Francisco Novella, 'Catedrático de Retórica en las escuelas de la insigne Universidad de Valencia, cuyos escritos son siempre muy estimados en todas manos' (Castillo Solórzano 1639, 30). We saw in the previous section of this study that the poems may reinforce an episode recounted in the prose history; into this category we can place, for instance, 'De la corona egipcia pretensores' (19), a piece by Castillo Solórzano on the first meeting of Cleopatra and Julius Caesar, and Jacinto Navarro's 'En montes de olas, cuya algente bruma' (90), a sonnet on one of Antony's captains who exhorted him to fight a ground war, rather than a battle at sea. Or the poems may underscore the lessons that the reader should derive from certain behaviours or actions; here we can adduce, for example, Pérez de Montalbán's sonnet on Pompey's death, which Castillo Solórzano introduces by

\footnotetext{
48 In his printed marginal note, Sayas gives the Latin of the quotation and its source, correctly, as 'Est enim proxima poetis, et quodam modo carmen solutum est,' from the first chapter of the tenth book of Quintilian's Institutio Oratoria: 'History is very close to the poets. In a sense it is a prose poem' (Quintilian 2002, 269).
} 
emphasising the added moral import conferred by the poem ('De aquí se saca cuán poco hay que fiar en poderes humanos' [17]). Such compositions, while enhancing the moral exemplarity which continually informs the prose history, can lapse into generic or diffuse ethical considerations; the most extreme case of this tendency is the second poem by Novella, 'Blanda lisonja a la Sirena imita' (86), a sonnet on flattery which features in the central part of Historia de Marco Antonio y Cleopatra but which evinces no real connection to the protagonists or events of the history.

The desire to establish commonality between prose history-writing and poetry is hardly untrodden ground at the time when Castillo Solórzano is drafting his book. In his mid-sixteenth-century manuscript Apuntes para el Memorial de las cosas necesarias para escribir la historia, Juan Páez de Castro, examining the role of elocuencia in historywriting, declares:

Es necesaria también la elocuencia para pintar no solo las facciones y disposición del cuerpo, sino también las condiciones, inclinaciones y pasiones del ánimo, y para dar los razonamientos convenientes a quien los hace, lo cual tiene la historia común con la poesía, como otras muchas cosas. (Martín Martín 1990, 57)

Cabrera de Córdoba examines the relationship of the two forms in more depth as he treats 'las partes y definición de la historia', albeit most of his observations seek to establish clear space between history and poetry; he claims that 'la diferencia es verdades, con que excluye la narración de la poesía, que es de mentiras; y así es mucha la diferencia y desconveniencia entre la historia y la poesía, no por ser ésta en verso' (Cabrera de Córdoba 1948, 24), and he counterpoints the historian's pursuit of the particular or actual with the poet's desire for the universal or ideal (25). Nevertheless, he accepts that both poetry and history share the features of 'condenando los vicios, alabando las virtudes, e introduc[iendo] los parlamentos y consultas. Ambas con suma industria atienden a la guardia de la prudencia y del decoro, enseñan, delectan, 
mueven, ayudan' (27), and in these regards the distinction is more one of character than simple separation: 'La historia tiene más de lo honesto, grave, ejemplar, como matrona ilustre y sabia. La poesía joven y gentil, alguna vez con gala y hermosura, lascivia, con licencia [...]' (Cabrera de Córdoba 1948, 28). The applicability of these assumptions to Historia de Marco Antonio y Cleopatra is beyond doubt, for, if the prose history conveys to the reader a consistent and rarely dull course of events and a generally unambiguous moral discourse (both generated by a hidden and skilful seaming of sources), the poetry of the volume, whose brevity permits a usually unobtrusive incorporation, amplifies occurrences and condemns and praises actions with increased gala y hermosura, and even perhaps a dash of lascivia and licencia, to borrow Cabrera de Córdoba's terms. The poems of Historia de Marco Antonio y Cleopatra are not merely rectificatory, as the conventional self-deprecation of the prologue affirms, and they are in most cases clearly more than decorative; rather, the two forms in Castillo Solórzano's book promote and reinforce the same narrative and the same moral vision: one of lust, greed, ambition and foolishness, qualities as pernicious and as widespread in the first part of the 1600s as they were when Rome was contorting towards its imperial destiny.

We will, however, remain to a great extent in the dark regarding the precise contours of Castillo Solórzano's poetic designs, in so far as these were conceived in support of his history; if it is reasonable to posit that the eleven poems penned by Castillo Solórzano himself are meant to concentrate the reader's attention upon certain events or behaviours more closely than upon others, the uncertainty which shrouds the method or methods by Castillo Solórzano obtained pieces from the other contributors does not allow us to state this with confidence of the rest of the poetry in the volume. With the exception of Lope's second-hand sonnet, we do not know which pieces were already in circulation, if any; if Castillo Solórzano did avail himself of existing compositions, this would inevitably have removed a degree of his own control over the content and focus. If poems were solicited from scratch by Castillo Solórzano, we do not know the extent of the specificity which accompanied the petition. The two contributors to Historia de Marco Antonio y Cleopatra whom we saw praised in Gracián Agudeza y arte de ingenio illustrate the problem. We noted above 
Castillo Solórzano's assertion that Francisco Diego de Sayas's sonnet (and, by extension, his other two) hails from an earlier part of his life and that he is no longer composing new verse, but the likelihood of Sayas's having a spare trio of sonnets on Antony and Cleopatra left over from his youthful poetic days is a coincidence which stretches credulity; that two of the three poems present episodes involving Cleopatra and poisons allows no obvious inference to be drawn either way, but the fact that all of the sonnets correspond fairly neatly to the prose treatment admits the possibility that the pieces were composed by Sayas upon a contemporary request made by Castillo Solórzano, perhaps even with the manuscript of the history made available to Sayas. On the other hand, Valdivielso's “" Recibe, oh mi Cleopatra, la postrera' displays not simply a weak bond with the surrounding prose, but rather a contradiction of it, as we noted earlier of Cruyllas's 'En un estrado que sostiene ufano', calqued on Plutarch's account where Castillo Solórzano had followed Cassius Dio. Valdivielso's poem comes directly after the scene of Antony's death by his own hand and imagines his dying words to Cleopatra, filling the speech with high-flown language declaiming his love for her and their conjoined destinies; in the prose, however, where Castillo Solórzano follows Plutarch closely, Antony is most concerned with the practicalities of Cleopatra's immediate future (he advises her to seek out Proculeius, Octavian's trusted lieutenant), before then expressing satisfaction in the positive aspects of his reputation, with a clear declaration of love for Cleopatra conspicuously absent. We might postulate that this was a pre-existing sonnet composed by Valdivielso independently of Historia de Marco Antonio y Cleopatra, and, while it is possible that Castillo Solórzano requested a poem from Valdivielso on Antony's self-murder, the discrepancy between the prose and poetry makes a detailed briefing improbable. 49 Were we to give Valdivielso the benefit of the doubt, we might argue that he has nevertheless captured the spirit of Antony and Cleopatra's affair and embodied an

49 As we have noted elsewhere in this study, both Lope and Jáuregui had had already composed sonnets on Antony and Cleopatra, and we find another piece on the pair at Actium which is independent of Castillo Solórzano's work: Antonio López de Vega's 'Determinado Amor, Marte dudoso' is included in the Poesías varias which he adds to the second edition of his Perfeto señor, in 1652 (López de Vega 1652, 127). 
essential truth of their intractably linked fates, but the point remains that Castillo Solórzano has allowed his close friend's contribution to disturb the flow of the history. We can grant that this is an extreme case, like the incongruous retention of the final address to Lucinda in Lope's 'Cleopatra a Antonio en oloroso vino', but it should caution us against assuming consistently rigorous planning on Castillo Solórzano's part and against declaring unqualified success in his employment of verse as an integral part of his history. 


\section{Bibliography}

Amada, José Félix de. 1650. Palestra numerosa austriaca en la victoriosa ciudad de Huesca al augustísimo consorcio de los católicos Reyes de España don Felipe el Grande y doña María Ana la Ínclita. Huesca: Juan Francisco de Larumbe.

Antonio, Nicolás. 1672. Bibliotheca Hispana, sive Hispanorum [...]. 2 vols. Rome: Nicolò Angelo Tinassi.

Arco, Ricardo del. 1950. “El poeta aragonés Juan de Moncayo, marqués de San Felices." Boletín de la Real Academia Española 30: 23-46 \& 225-255.

Arredondo, María Soledad. 2006. “Castillo Solórzano y la mixtura barroca: poesía, narrativa y teatro en La niña de los embustes, Teresa de Manzanares." In El Siglo de Oro en escena. Homenaje a Marc Vitse, edited by Odette Gorsse and Frédéric Serralta, 35-51. Toulouse: Presses Universitaires du Mirail.

Blecua, José Manuel, ed. 1945. "Poesías de Martín Miguel Navarro." Archivo de Filología Aragonesa 1: 217-317.

Boaistuau, Pierre. 1586. Historias prodigiosas y maravillosas de diversos sucesos acaescidos en el mundo. Translated by Andrea Pescioni. Medina del Campo: Francisco del Canto.

Bonilla Cerezo, Rafael. 2012. “Alonso de Castillo Solórzano: bio-bibliografía completa." Tintas. Quaderni di Letterature Iberiche e Iberoamericane 2: 243-282.

Borja, Francisco de. 1648. Obras en verso. Madrid: Diego Díaz de la Carrera.

Bradbury, Jonathan David. 2016. “The Unstated Sources of Cristóbal Suárez de Figueroa's Varias noticias importantes a la humana comunicación (1621)." Modern Language Review 111: 703-726.

Cabrera de Córdoba, Luis. 1948. De historia, para entenderla y escribirla. Edited by Santiago Montero Díaz. Madrid: Instituto de Estudios Políticos.

Castillo Solórzano, Alonso de. 1634. Fiestas del jardín. Valencia: Silvestre Esparsa.

Castillo Solórzano, Alonso de. 1639. Historia de Marco Antonio y Cleopatra. Zaragoza: Pedro Vergés. 
Castillo Solórzano, Alonso de. 1907. Tiempo de regocijo, y carnestolendas de Madrid. In 'Las harpías en Madrid' y 'Tiempo de regocijo'. Novelas de don Alonso de Castillo Solórzano. Edited by Emilio Cotarelo y Mori. Madrid: Librería de los Bibliófilos Españoles.

Castillo Solórzano, Alonso de. 1944. Huerta de Valencia. Prosas y versos en las academias de ella. Madrid: Sociedad de Bibliófilos Españoles.

Castillo Solórzano, Alonso de. 2012. Picaresca femenina de Alonso de Castillo Solórzano: 'Teresa de Manzanares' y 'La garduña de Sevilla'. Edited by Fernando Rodríguez de Mansilla. Madrid: Iberoamericana.

Cerda, Juan de la. 1599. Vida política de todos los estados de mujeres. Alcalá de Henares: Juan Gracián.

Cossío, José María de. 1998. Fábulas mitológicas en España. 2 vols. 2nd ed. Madrid: Istmo.

Dadson, Trevor. 2010. Historia de la impresión de las 'Rimas' de Lupercio y Bartolomé Leonardo de Argensola. Zaragoza: Institución «Fernando el Católico».

Díez de Aux, Luis. 1619. Compendio de las fiestas que ha celebrado la ciudad de Zaragoza, por haber promovido Felipe tercero de Castilla y segundo de Aragón al ilustrísimo señor don fray Luis Aliaga [...] en el oficio de Inquisidor General de España. Zaragoza: Juan de Lanaja.

Dio, Cassius. 1565. De' fatti de' romani. Translated by Francesco Baldelli. Venice: Gabriele Giolito.

Fernández-Santamaría, José A. 1980. “Reason of State and Statecraft in Spain (15951640)." Journal of the History of Ideas 41: 355-379.

Fuentes, Alonso de. 1587. Libro de los cuarenta cantos. Alcalá de Henares: Juan Gracián.

Funes, Juan Agustín de. 1639. Coronica de la ilustrísima milicia y sagrada religión de San Juan Bautista de Jerusalén [...] Segunda parte. Zaragoza: Pedro Vergés.

Gil Pujol, Francisco Xavier. 2003. “Las fuerzas del Rey. La generación que leyó a Botero." In Le forze del principe. Recursos, instrumentos y límites en la práctica del poder 
soberano en los territorios de la monarquía hispánica, edited by José Javier Ruiz Ibáñez, Mario Rizzo, and Gaetano Sabatini, vol. 2, 969-1022. Murcia: Universidad de Murcia. Giorgi, Giulia. 2014. “Alonso de Castillo Solórzano reescritor de sí mismo: algunas notas sobre los Escarmientos de amor moralizados y el Lisardo enamorado." Edad de Oro 33: 257-266

Goldsworthy, Adrian. 2010. Antony and Cleopatra. New Haven: Yale University Press. González Cañal, Rafael. 2008. “Cleopatra, una figura femenina del teatro de Rojas.” In Rojas Zorrilla en su IV centenario, edited by Felipe B. Pedraza Jiménez, Rafael González Cañal, and Elena E. Marcello, 269-291. Cuenca: Universidad de Castilla-La Mancha.

Gracián, Baltasar. 2004. Agudeza y arte de ingenio. 2 vols. Edited by Ceferino Peralta, Jorge M. Ayala, and José María Andreu. Zaragoza: Prensas Universitarias de Zaragoza.

Grande de Tena, Pedro. 1639. Lágrimas panegíricas a la temprana muerte de [...] Juan Pérez de Montalbán. Madrid: Imprenta del Reino.

Jauralde Pou, Pablo, ed. 2010. Diccionario filológico de literatura española (siglo XVII). 2 vols. Madrid: Castalia.

Jáuregui, Juan de. 1618. Rimas. Seville: Francisco de Lyra Varreto.

Jiménez Belmonte, Javier. 2011a. “De Cleopatra y mecenazgos: la Historia de Marco Antonio y Cleopatra de Alonso de Castillo Solórzano (Zaragoza, 1639)." In Compostella Aurea. Actas del VIII Congreso de la AISO, edited by Antonio Azaustre Galiana and Santiago Fernández Mosquera, vol. 2, 315-322. Santiago de Compostela: Universidade de Santiago de Compostela.

Jiménez Belmonte, Javier. 2011b. “Historiar el Oriente: Cleopatra en la historiografía española del XVI." eHumanista 17: 286-310.

Jones, Prudence J. 2006. Cleopatra. The Last Pharaoh. London: Haus.

Kagan, Richard L. 2009. Clio \& the Crown. The Politics of History in Medieval and Early Modern Spain (Baltimore: Johns Hopkins University Press). 
Kamen, Henry. 1991. Spain, 1469-1714. A Society of Conflict. 2nd ed. London: Longman.

Kennedy, Ruth L. 1968. “Pantaleon de Ribera, 'Sirene,' Castillo y Solórzano, and the Academia de Madrid in Early 1625." In Homage to John M. Hill, edited by Walter Poesse, 189-200. Bloomington: Indiana University Press.

King, Willard F. 1963. Prosa novelística y academias literarias en el siglo XVII. Madrid: Real Academia Española.

Kleiner, Diana E.E. 2005. Cleopatra and Rome. Cambridge, MA: Harvard University Press.

Latassa, Félix de. 1799. Biblioteca nueva de los escritores aragoneses que florecieron desde el año de 1641 hasta 1680. Pamplona: Joaquín de Domingo.

Leonardo Argensola, Lupercio, and Bartolomé Leonardo de Argensola. 1634 [1633]. Rimas de Lupercio y del doctor Bartolomé Leonardo de Argensola. Zaragoza: Hospital Real y General de Nuestra Señora de Gracia.

López de Vega, Antonio. 1652. El perfeto señor. Sueño político. Con otros varios Discursos y últimas Poesías. Madrid: Imprenta Real.

López Poza, Sagrario. 1990. “Florilegios, polyantheas, repertorios de sentencias y lugares comunes. Aproximación bibliográfica." Criticón 49: 61-76.

Martín, Pedro. 1618. Certamen poético a las fiestas de la translación de la reliquia de San Ramón Nonat. Zaragoza: Juan de Lanaja.

Martín Martín, Teodoro. 1990. Vida y obra de Juan Páez de Castro. Guadalajara: Institución Provincial de Cultura Marqués de Santillana.

Mas i Usó, Pasqual. 1999. Academias valencianas del Barroco. Descripción y diccionario de poetas. Kassel: Reichenberger.

Mexía, Pedro. 1655. Historia imperial y cesárea. Madrid: Melchor Sánchez.

Mexía, Pedro. 2003. Silva de varia lección. Edited by Isaías Lerner. Madrid: Castalia. 
Mexía, Pedro. 2004. Diálogos o Coloquios. Edited by Antonio Castro Díaz. Madrid: Cátedra.

Millar, Fergus. 1964. A Study of Cassius Dio. Oxford: Clarendon Press.

Moncayo, Juan de. 1976. Rimas. Edited by Aurora Egido. Madrid: Espasa-Calpe.

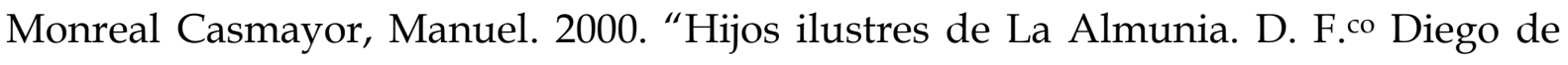
Sayas Ravanera y Ortubia, Cronista de Aragón." Ador 5: 93-110.

Parke, Herbert W. 1978. “Castalia.” Bulletin de Correspondance Hellénique 102: 199-219

Patrizi, Francesco. 1591. De reino y de la institución del que ha de reinar. Translated by Enrique Garcés. Madrid: Luis Sánchez.

Pelling, C.B.R. 1995. "Plutarch's Adaptation of his Source-Material." In Essays on Plutarch's 'Lives', edited by Barbara Scardigli, 125-154. Oxford: Oxford University Press.

Pineda, Juan de. 1588. Los treinta libros de la Monarquía eclesiástica, o Historia universal del mundo. 5 vols. Salamanca: Juan Fernández.

Pineda, Juan de. 1963-64. Diálogos familiares de la agricultura cristiana. 5 vols. Edited by Juan Meseguer Fernández. Madrid: Atlas.

Plutarch. 1555. La seconda parte delle Vite. Translated by Lodovico Domenichi. Venice: Gabriele Giolito.

Plutarch. 1920. Demetrius and Antony. Pyrrhus and Gaius Marius. Vol. 9 of Lives. Translated by Bernadotte Perrin. Cambridge, MA: Harvard University Press, 1914-26. Plutarch. 1988. Life of Antony. Edited by C.B.R. Pelling. Cambridge: Cambridge University Press.

Pocock, J.G.A. 2003. The First Decline and Fall. Vol. 3 of Barbarism and Religion. Cambridge: Cambridge University Press, 1999-2015. 
Quintilian. 2002. The Orator's Education. Books 9-10. Vol. 4 of The Orator's Education. Edited and translated by Donald A. Russell. Cambridge, MA: Harvard University Press.

Rennert, Hugo. 1908. "Marco Antonio y Cleopatra. A Tragedy by Diego López de Castro." Revue Hispanique 19: 184-237.

Sainz de la Maza, Carlos. 2009. “El banquete de Cleopatra, I: los textos y sus antecedentes." In Literatura, política y fiesta en el Madrid de los Siglos de Oro, edited by Esther Borrego Gutiérrez and Catalina Buezo Canalejo, 421-451. Madrid: Visor.

Stradling, R.A. 1988. Philip IV and the Government of Spain, 1621-1665. Cambridge: Cambridge University Press.

Sullivan, Richard D. 1990. Near Eastern Royalty and Rome, 100-30 BC. Toronto: University of Toronto Press.

Vega, Lope de. 1621. La Filomena, con otras diversas rimas, prosas y versos. Barcelona: Sebastián de Cormel.

Vega, Lope de. 1624. Parte diecinueve y la mejor parte de las comedias de Lope de Vega Carpio. Madrid: Juan González.

Vega, Lope de. 1973. El peregrino en su patria. Edited by Juan Bautista Avalle-Arce. Madrid: Castalia.

Vega, Lope de. 1993-94. Rimas. 2 vols. Edited by Felipe B. Pedraza Jiménez. Ciudad Real: Universidad de Castilla-La Mancha.

Vega, Lope de. 2007. Laurel de Apolo. Edited by Antonio Carreño. Madrid: Cátedra. Volkmann, Hans. 1958. Cleopatra. A Study in Politics and Propaganda. Translated by T.J. Cadoux. London: Elek.

Wilamowitz-Moellendorf, U. von. 1995. "Plutarch as Biographer." In Essays on Plutarch's 'Lives', edited by Barbara Scardigli, 47-74. Oxford: Oxford University Press. Williamson, Marilyn L. 1974. Infinite Variety: Antony and Cleopatra in Renaissance Drama and Earlier Tradition. Mystic, CT: Lawrence Verry. 
Zaragoza Ayarza, Francisco. 2009. “Francisco Diego de Sayas Rabanera y Ortubia, historiador." Rolde 129.6: 4-11. 